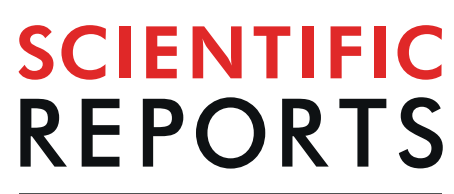

natureresearch

\title{
OPEN Microbial characterization and fermentative characteristics of crop maize ensiled with unsalable vegetables
}

Received: 10 April 2019
Accepted: 22 August 2019

Published online: 12 September 2019

\author{
Kristian Hooker ${ }^{1}$, Daniel L. Forwood $\mathbb{C}^{1,4}$, Eleonora Caro ${ }^{1,2}$, Yuxin Huo ${ }^{1}$, Devin B. Holman $\mathbb{D}^{3}$, \\ Alex V. Chaves $\mathbb{D B}^{1}$ \& Sarah J. Meale ${ }^{4}$
}

Incorporation of carrot or pumpkin at 0,20 or $40 \%$ dry matter (DM-basis) with crop maize, with or without a silage inoculant was evaluated after 70 days ensiling for microbial community diversity, nutrient composition, and aerobic stability. Inclusion of carrots or pumpkin had a strong effect on the silage bacterial community structure but not the fungal community. Bacterial microbial richness was also reduced $(P=0.01)$ by increasing vegetable proportion. Inverse Simpson's diversity increased $(P=0.04)$ by $18.3 \%$ with carrot maize silage as opposed to pumpkin maize silage at 20 or $40 \% \mathrm{DM}$. After $70 \mathrm{~d}$ ensiling, silage bacterial microbiota was dominated by Lactobacillus spp. and the fungal microbiota by Candida tropicalis, Kazachstania humilis and Fusarium denticulatum. After $14 \mathrm{~d}$ aerobic exposure, fungal diversity was not influenced $(P \geq 0.13)$ by vegetable type or proportion of inclusion in the silage. Inoculation of vegetable silage lowered silage surface temperatures on day-7 $(P=0.03)$ and day-14 $(P \leq 0.01)$ of aerobic stability analysis. Our findings suggest that ensiling unsalable vegetables with crop maize can successfully replace forage at 20 or $40 \%$ DM to produce a high-quality livestock feed.

Despite heightening concerns over food security, up to $1.6 \mathrm{Gt}$ of food is wasted globally each year ${ }^{1,2}$. Within Australia, $\sim 40 \%$ of vegetables are rejected by commercial grading standards due to cosmetic defects, regardless of their nutritional quality or suitability for consumption. This amounts to 1.3 billion tonnes of food waste and is estimated to cost Australia $\$ 8.4$ billion annually ${ }^{3,4}$. Current post-grading avenues for unsalable vegetables include incineration, composting and biofuel production. However, in developing countries, food waste often enters landfills and waterways ${ }^{5}$. Consequently, considerable environmental damage is caused through their rapid decomposition and resultant greenhouse gas production ${ }^{6}$. Thus, necessitating an alternative avenue for unsalable vegetables.

Previous studies have identified unsalable vegetables as potential feed additives in livestock diets due to their high palatability, high concentration of total digestible nutrients ${ }^{7}$, and antioxidant properties ${ }^{8}$. Recently, the replacement of common feed additives, wheat bran or soybean meal, with vegetables sourced from markets at up to $275 \mathrm{~g} \mathrm{~kg}^{-1} \mathrm{DM}$ in growing bull diets resulted in similar rumen degradability ${ }^{9}$. Additionally, as the crude protein values range between $5 \%$ and $18 \%$ dry matter (DM), and with energy values ranging from $8.8 \mathrm{MJ} / \mathrm{Kg} \mathrm{DM}$ in pumpkins, up to $13.8 \mathrm{MJ} / \mathrm{Kg} \mathrm{DM}$ in carrots, it is expected that they can be effectively integrated in ruminant diets to support targeted growth rates. Yet, due to their high moisture content of $30 \%$, a preservation method is required to extend their shelf life.

Identification of the ideal ensiling ratio and crop selection is paramount. Here, we investigated the use of maize. Previously, ensiled crop maize successfully replaced grass silage and was associated with increased feed intake, utilisation of metabolizable energy and improvements in carcase weight gain of crossbred beef cattle ${ }^{10}$. Prior to ensiling vegetables, consideration must be given to the effect of sanitising agents commonly used in

\footnotetext{
${ }^{1}$ School of Life and Environmental Sciences, Faculty of Science, University of Sydney, Camperdown, NSW, Australia. ${ }^{2}$ Department of Agricultural, Forestry and Food Science, University of Turin, Torino, TO, Italy. ${ }^{3}$ Lacombe Research and Development Centre, Agriculture and Agri-Food Canada, Lacombe, AB, Canada. ${ }^{4}$ School of Agriculture and Food Sciences, Faculty of Science, University of Queensland, Gatton, QLD, Australia. Kristian Hooker and Daniel L. Forwood contributed equally. Correspondence and requests for materials should be addressed to S.J.M. (email: s. meale@uq.edu.au)
} 


\begin{tabular}{|c|c|c|c|c|c|c|c|c|c|c|c|}
\hline \multirow[b]{2}{*}{ Parameter $^{1}$} & \multirow[b]{2}{*}{$0 \%$} & \multicolumn{2}{|c|}{ Carrots } & \multicolumn{2}{|c|}{ Pumpkin } & \multirow[b]{2}{*}{ SEM } & \multirow[b]{2}{*}{ Veg } & \multicolumn{4}{|c|}{ P-values $^{2}$} \\
\hline & & $20 \%$ & $40 \%$ & $20 \%$ & $40 \%$ & & & Level & Veg $\times$ Level & Linear & Quadratic \\
\hline $\begin{array}{l}\text { Dry matter } \\
\text { content, \% }\end{array}$ & $37.00 \mathrm{a}$ & $35.30 \mathrm{a}$ & $31.00 \mathrm{~b}$ & $29.00 \mathrm{~b}$ & $22.40 \mathrm{c}$ & 1.49 & $<0.01$ & $<0.01$ & 0.02 & $<0.01$ & 0.79 \\
\hline Dry matter loss, $\mathrm{g}$ & 62.50 & 77.50 & 78.80 & 82.50 & 98.80 & 7.84 & 0.24 & 0.02 & 0.47 & 0.01 & 0.53 \\
\hline Silage $\mathrm{pH}$ & 3.80 & 3.90 & 4.00 & 3.90 & 3.90 & 0.09 & 0.70 & 0.18 & 0.84 & 0.10 & 0.53 \\
\hline Ash, \% DM & $4.90 \mathrm{~b}$ & $5.40 \mathrm{a}$ & $5.40 \mathrm{a}$ & $5.20 \mathrm{~b}$ & $5.90 \mathrm{a}$ & 0.14 & 0.33 & $<0.01$ & 0.05 & $<0.01$ & 0.74 \\
\hline NDF, \% in DM & 44.60 & 41.60 & 44.10 & 43.50 & 43.30 & 1.43 & 0.76 & 0.39 & 0.62 & 0.55 & 0.22 \\
\hline $\mathrm{CP}, \%$ in $\mathrm{DM}$ & 6.30 & 7.80 & 8.10 & 7.80 & 8.50 & $\mathrm{n} / \mathrm{a}$ & $\mathrm{n} / \mathrm{a}$ & $\mathrm{n} / \mathrm{a}$ & $\mathrm{n} / \mathrm{a}$ & $\mathrm{n} / \mathrm{a}$ & $\mathrm{n} / \mathrm{a}$ \\
\hline $\begin{array}{l}\text { Crude fat, \% in } \\
\text { DM }\end{array}$ & 3.00 & 3.60 & 3.50 & 3.50 & 3.90 & 0.19 & 0.57 & 0.01 & 0.4 & $<0.01$ & 0.29 \\
\hline NFC, \% in DM & 41.20 & 41.60 & 38.90 & 40.00 & 38.40 & $\mathrm{n} / \mathrm{a}$ & $\mathrm{n} / \mathrm{a}$ & $\mathrm{n} / \mathrm{a}$ & $\mathrm{n} / \mathrm{a}$ & $\mathrm{n} / \mathrm{a}$ & $\mathrm{n} / \mathrm{a}$ \\
\hline \multicolumn{12}{|c|}{ Volatile fatty acids, $m M$} \\
\hline Acetic acid & 13.60 & 19.80 & 18.40 & 22.00 & 22.50 & 0.88 & 0.01 & $<0.01$ & 0.10 & $<0.01$ & $<0.01$ \\
\hline Propionic acid & $0.32 \mathrm{~b}$ & $0.25 \mathrm{~b}$ & $0.38 \mathrm{~b}$ & $0.66 \mathrm{a}$ & $0.31 \mathrm{~b}$ & 0.08 & 0.13 & 0.25 & 0.03 & 0.73 & 0.11 \\
\hline Butyric acid & 0.09 & 0.09 & 0.10 & 0.10 & 0.12 & 0.01 & 0.13 & 0.09 & 0.40 & 0.04 & 0.35 \\
\hline Total VFA & 14.70 & 20.30 & 19.10 & 23.00 & 23.10 & 0.87 & 0.01 & $<0.01$ & 0.11 & $<0.01$ & $<0.01$ \\
\hline \multicolumn{12}{|c|}{ Organic acid concentration, $m M$} \\
\hline Succinic acid & 0.27 & 0.57 & 0.66 & 0.49 & 0.89 & 0.18 & 0.74 & 0.12 & 0.73 & 0.05 & 0.95 \\
\hline Lactic acid & 8.60 & 4.76 & 9.60 & 5.08 & 2.88 & 1.63 & 0.17 & 0.10 & 0.18 & 0.21 & 0.14 \\
\hline Ethanol, \% & 0.11 & 0.11 & 0.12 & 0.13 & 0.13 & 0.0070 & 0.18 & 0.26 & 0.49 & 0.14 & 0.50 \\
\hline
\end{tabular}

Table 1. Physio-chemical characteristics, nutrient composition, and organic acid profile of maize ensiled with unsalable vegetables after 70 days of ensiling. ${ }^{1} \mathrm{NDF}=$ Neutral detergent fiber; $\mathrm{CP}=$ Crude protein; $\mathrm{NFC}=$ nonfibrous carbohydrates, $100-(\mathrm{CP}+\mathrm{NDF}+\mathrm{CF}+\mathrm{ash}) .{ }^{2} \mathrm{P}$-values: Vegetable, carrot or pumpkin; Level, proportion of vegetable in silage on DM basis; Vegetable $\times$ Level, interaction. Statistical significance declared at $\mathrm{P} \leq 0.05$. Means with different letters $-\mathrm{a}, \mathrm{b}, \mathrm{c}$ differ $(\mathrm{P} \leq 0.05)$.

vegetable processing plants on microbial community profiles. For example, sodium hypochlorite $(\mathrm{NaClO})$ is damaging to cellular transport mechanisms in pathogens such as Escherichia coli ${ }^{11}$ and has been shown to reduce the proliferation and abundance of pathogenic bacteria, yeasts, moulds and spoilage microbes in carrot peels ${ }^{12}$. To overcome this, the use of silage inoculant will be investigated. Previous literature suggests the use of vegetable residues, with or without a lactic acid-bacteria (LAB) inoculant, in a crop silage can produce a highly digestible feed that positively affects the profile of acetic and propionic acids ${ }^{5,13}$.

Therefore, the objectives of this study were to determine whether unsalable vegetables at varying proportions could be successfully ensiled with crop maize to produce a silage of high nutritional value, which maintains aerobic stability, and quality through in vitro fermentation, and to characterise the bacterial and fungal microbiota of the resulting silage. We hypothesised that fresh, unsalable vegetables ensiled with crop maize would produce a silage with greater acetic and propionic acid concentrations, increase the overall microbial diversity at higher vegetable levels, and improve aerobic stability with the introduction of a second-generation microbial inoculant in the vegetable silage.

\section{Results}

Chemical composition of silage. The chemical composition of maize at harvest, in addition to carrot and pumpkin are presented in Supplementary Table 1. The dry matter (DM) content of maize silage was affected $(\mathrm{P}=0.02)$ by the interaction of vegetable type $\times$ level (Table 1$)$. The DM content of $100 \%$ ensiled maize was greater $(\mathrm{P}=0.02)$ than with the addition of $40 \%$ of either vegetable, or $20 \%$ pumpkin, but was similar to $20 \%$ carrot inclusion. When comparing across vegetable type, the inclusion of pumpkin resulted in wetter $(\mathrm{P}=0.02)$ silage, compared to carrots at both 20 and 40\% DM inclusion rates. Similarly, DM loss (g) increased linearly $(\mathrm{P}=0.01)$ with increasing amounts of vegetable in the silage.

The percentage of ash was affected by the interaction of vegetable $\times$ level $(\mathrm{P}=0.05)$, where $20 \%$ and $40 \%$ carrot had similar concentrations of ash (5.4\%) in the DM and were greater than the control (4.9\%; Table 1). Conversely, silage containing pumpkin showed a linear $(\mathrm{P} \leq 0.01)$ increase in the percentage of ash in the silage (Table 1$)$. Concentrations of NDF (\% in the $\mathrm{DM})$ or silage $\mathrm{pH}$ were not affected $(\mathrm{P} \geq 0.22)$ by the addition of either vegetable (Table 1). Crude fat concentration $(\%$ in the DM) increased linearly $(\mathrm{P}<0.01)$ with increasing vegetable inclusion, regardless of the vegetable type. Statistical analysis of crude protein was not possible since only 1 sample per treatment was analyzed.

Organic acid concentrations. Total volatile fatty acids (VFA) and concentrations of acetic acid (mM) were greater $(\mathrm{P}<0.01)$ in silages containing pumpkin, compared to control or carrot treatments (Table 1$)$. Additionally, a quadratic increase $(\mathrm{P}<0.01)$ in both total VFA and acetic acid concentration were observed with increasing inclusion of carrot or pumpkin. The concentration of propionic acid $(\mathrm{mM})$ in maize silage was affected by the interaction of vegetable $\times$ level $(\mathrm{P}=0.03)$, where pumpkin inclusion at $20 \% \mathrm{DM}$ increased propionic acid concentrations by $48 \%$, compared to the control. Butyrate tended $(\mathrm{P}=0.09)$ to increase with increasing inclusion of vegetables in the silage. However, no other effects were observed on organic acid concentrations. 


\begin{tabular}{|c|c|c|c|c|c|c|c|c|c|c|c|}
\hline \multirow[b]{2}{*}{ Day } & \multirow[b]{2}{*}{$0 \%$} & \multicolumn{2}{|c|}{ Carrots } & \multicolumn{2}{|c|}{ Pumpkin } & \multirow[b]{2}{*}{ SEM } & \multicolumn{5}{|c|}{ P-values ${ }^{\mathrm{a}}$} \\
\hline & & $20 \%$ & $40 \%$ & $20 \%$ & $40 \%$ & & Veg & Level & Veg $\times$ Level & Linear & Quadratic \\
\hline 1 & 22.96 & 22.96 & 22.8 & 22.84 & 22.76 & 0.13 & 0.63 & 0.38 & 0.91 & 0.17 & 0.8 \\
\hline 2 & 22.76 & 22.53 & 22.54 & 22.28 & 22.29 & 0.16 & 0.2 & 0.05 & 0.67 & 0.04 & 0.2 \\
\hline 3 & 23.88 & 23.93 & 23.35 & 23.75 & 23.81 & 0.16 & 0.51 & 0.18 & 0.18 & 0.09 & 0.43 \\
\hline 4 & 22.81 & 22.83 & 22.44 & 22.5 & 22.66 & 0.22 & 0.86 & 0.49 & 0.46 & 0.24 & 0.93 \\
\hline 5 & 23.82 & 23.84 & 23.41 & 23.77 & 23.74 & 0.25 & \begin{tabular}{|l|}
0.67 \\
\end{tabular} & 0.55 & 0.71 & 0.32 & 0.63 \\
\hline 6 & 23.72 & 23.71 & 23.73 & 23.59 & 23.6 & 0.39 & 0.79 & 0.98 & 0.98 & 0.89 & 0.89 \\
\hline 7 & 23.6 & 23.65 & 23.55 & 23.71 & 23.82 & 0.21 & 0.53 & 0.91 & 0.79 & 0.71 & 0.84 \\
\hline 8 & 22.71 & 22.74 & 22.59 & 22.42 & 22.5 & 0.3 & 0.58 & 0.84 & 0.87 & 0.58 & 0.85 \\
\hline 9 & 23.49 & 23.45 & 23.39 & 23.19 & 23.36 & 0.35 & 0.73 & 0.89 & 0.93 & 0.74 & 0.71 \\
\hline 10 & 23.45 & 23.3 & 23.24 & 23.27 & 23.41 & 0.22 & 0.8 & 0.73 & 0.88 & 0.56 & 0.59 \\
\hline 11 & 25.03 & 25.03 & 24.94 & 24.84 & 24.92 & 0.29 & 0.76 & 0.92 & 0.94 & 0.72 & 0.84 \\
\hline 12 & 24.84 & 24.84 & 24.72 & 24.76 & 24.62 & 0.55 & \begin{tabular}{|l|}
0.9 \\
\end{tabular} & 0.95 & 1.00 & 0.75 & 0.92 \\
\hline 13 & 23.91 & 24.01 & 23.89 & 23.86 & 24.02 & 0.54 & 0.99 & 1.00 & \begin{tabular}{|l|}
0.97 \\
\end{tabular} & 0.93 & 1.00 \\
\hline 14 & 23.47 & 23.31 & 23.42 & 23.18 & 23.43 & 0.14 & 0.72 & \begin{tabular}{|l|l|}
0.27 \\
\end{tabular} & 0.86 & 0.73 & 0.12 \\
\hline
\end{tabular}

Table 2. Aerobic stability of maize silage after 70 days of ensiling, based on surface temperature $\left({ }^{\circ} \mathrm{C}\right)$ of silage. aP-values for the treatments: Vegetable, carrot or pumpkin; Level, proportion of vegetable in silage on DM basis; Vegetable $\times$ Level, interaction. Statistical significance declared at $\mathrm{P} \leq 0.05$.

\begin{tabular}{|c|c|c|c|c|c|c|c|c|c|c|c|}
\hline & \multirow[b]{2}{*}{0} & \multicolumn{2}{|c|}{ Carrots } & \multicolumn{2}{|c|}{ Pumpkin } & \multirow[b]{2}{*}{ SEM } & \multicolumn{5}{|c|}{ P-values ${ }^{\mathbf{a}}$} \\
\hline & & $20 \%$ & $40 \%$ & $20 \%$ & $40 \%$ & & Veg & Level & Veg $\times$ Level & $\mathbf{L}$ & $\mathbf{Q}$ \\
\hline \multicolumn{12}{|l|}{ Bacteria - Initial } \\
\hline Number of OTUs & 33.8 & 28.3 & 26.5 & 29.8 & 29 & 1.59 & 0.33 & 0.01 & 0.74 & $<0.01$ & 0.23 \\
\hline Shannon diversity & 2.07 & 1.98 & 1.98 & 2.16 & 2.13 & 0.036 & $<0.01$ & 0.85 & 0.06 & 0.69 & 0.69 \\
\hline Simpsons diversity & 5.52 & 5.26 & 5.06 & 6.08 & 6.07 & 0.292 & 0.24 & 0.88 & 0.47 & 0.9 & 0.71 \\
\hline \multicolumn{12}{|l|}{ Bacteria - Silage } \\
\hline Number of OTUs & 55 & 61 & 55.8 & 52.3 & 37.3 & 4.41 & 0.03 & 0.09 & 0.15 & 0.08 & 0.15 \\
\hline Shannon diversity & 2.55 & 2.79 & 2.44 & 2.58 & 2.22 & 0.347 & 0.66 & 0.69 & 0.94 & 0.59 & 0.5 \\
\hline Simpsons diversity & 10.2 & 10 & 6.9 & 8.3 & 4.4 & 0.74 & 0.04 & $<0.01$ & 0.26 & $<0.01$ & 0.09 \\
\hline \multicolumn{12}{|l|}{ Fungi - Silage } \\
\hline Number of OTUs & 33 & 39 & 34.8 & 33.8 & 44.5 & 4.02 & 0.66 & 0.29 & 0.21 & 0.13 & 0.99 \\
\hline Shannon diversity & 2.2 & 2.23 & 2.21 & 2.28 & 2.35 & 0.068 & 0.27 & 0.49 & 0.6 & 0.25 & 0.79 \\
\hline Simpsons diversity & 5.25 & 5.62 & 5.65 & 5.9 & 5.67 & 0.426 & 0.78 & 0.47 & 0.94 & 0.36 & 0.43 \\
\hline \multicolumn{12}{|c|}{ Fungi - Aerobic Stability } \\
\hline Number of OTUs & 27.7 & 40.6 & 42.1 & 61.1 & 36.3 & 18.63 & 0.78 & 0.43 & 0.81 & 0.6 & 0.38 \\
\hline Shannon diversity & 2.06 & 2.71 & 2.67 & 3.24 & 2.52 & 0.593 & 0.81 & 0.31 & 0.85 & 0.43 & 0.3 \\
\hline Simpsons diversity & 5.8 & 10.1 & 9.1 & 14 & 12.1 & 3.72 & 0.53 & 0.37 & 0.85 & 0.33 & 0.37 \\
\hline
\end{tabular}

Table 3. Alpha diversity of the silage bacterial and fungal microbiota by treatments with increasing proportions of carrot or pumpkin. ${ }^{a} \mathrm{P}$-values for the treatments: Vegetable, carrot or pumpkin; Level, proportion of vegetable in silage on DM basis; Vegetable $\times$ Level, interaction. Statistical significance declared at $\mathrm{P} \leq 0.05$.

Silage aerobic stability. Surface temperature $\left({ }^{\circ} \mathrm{C}\right)$ of maize was not affected by vegetable inclusion or vegetable type, except for a decline in surface temperature $(\mathrm{P}=0.05)$ with increasing inclusion of vegetable on the second day of the 14-day aerobic stability trial (Table 2; Supplementary Table 2).

Bacterial and fungal diversity and composition of silage. Alpha diversity measures for the original crop, silage at day 0 and day 14 after opening are presented in Table 3. A linear decrease $(P=0.01)$ in the number of bacterial operational taxonomic units (OTUs) was observed with increasing amounts of vegetable prior to ensiling. The addition of pumpkin and inoculant to the silage produced greater $(\mathrm{P} \leq 0.003 ; 5.47$ and $9.64 \%$, respectively) diversity (as indicated by Shannon diversity), compared to silage with carrots and without inoculant. There was no effect of vegetable, or level on the inverse Simpson's diversity index of bacteria in the maize crop prior to ensiling.

The number of bacterial and fungal OTUs and Shannon diversity were not affected $(\mathrm{P} \geq 0.15)$ by treatments upon silage opening (Table 3$)$. However, carrots incorporated into the maize silage had $18.3 \%$ greater $(\mathrm{P}=0.04)$ inverse Simpsons diversity, compared to maize silage with pumpkin. A linear decrease $(\mathrm{P}<0.01)$ in Simpsons diversity was observed with increasing levels of vegetable in the maize silage. Fungal diversity was not affected 
A

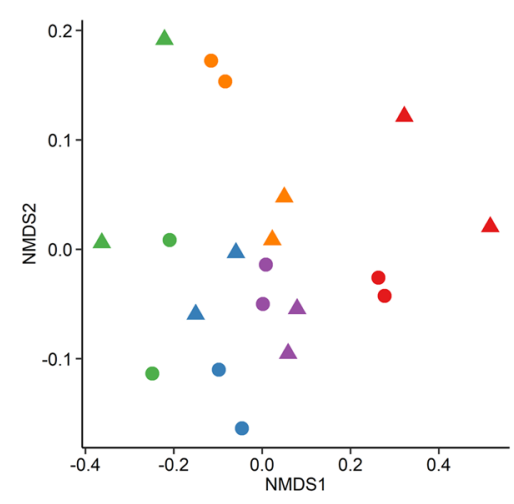

B

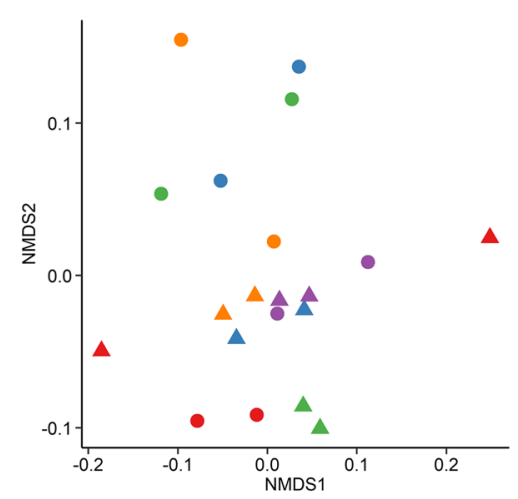

C

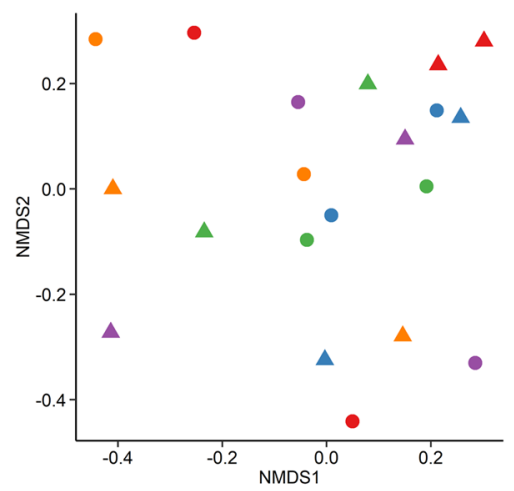

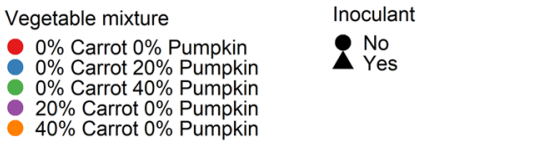

Figure 1. Non-metric dimensional scaling (NMDS) plot of the Bray-Curtis dissimilarities of the (A) bacterial microbiota in maize silage (Stress $=0.07)$, (B) fungal microbiota in maize silage (Stress $=0.13$ ), and $(\mathbf{C})$ fungal microbiota in silage following $14 \mathrm{~d}$ aerobic exposure (Stress $=0.18$ ), by vegetable mixture and use of an inoculant.

$(\mathrm{P} \geq 0.13)$ by vegetable type, concentration, inoculant addition or interactions upon silage opening after 14 days of aerobic stability (Table 3 ).

The bacterial community structure of the silage was strongly affected by ensiling with either $20 \%$ or $40 \%$ carrot or pumpkin based on the Bray-Curtis dissimilarity between samples (Fig. $1 \mathrm{~A} ; \mathrm{R}^{2}=0.72 ; \mathrm{P} \leq 0.001$ ). There was also a significant, but weak, effect from the use of an inoculant $\left(\mathrm{R}^{2}=0.05 ; \mathrm{P}=0.03\right)$. All silages were dominated by Lactobacillus spp. after 70 days ensiling, regardless of vegetable (Fig. 2). However, there was a greater relative abundance of Lactobacillus spp. in the $40 \%$ carrot and $40 \%$ pumpkin silages, compared with the $100 \%$ maize silage (Supplementary Table 3). Members of the Klebsiella, Pediococcus, Salmonella and Weissella genera were more abundant in the $100 \%$ maize treatment.

The fungal community structure of maize silage was not affected by vegetable mixture (Fig. $1 \mathrm{~B} ; \mathrm{P} \geq 0.05$ ), although there was an effect from the use of inoculant $\left(\mathrm{R}^{2}=0.09 ; \mathrm{P}=0.03\right)$. Silage fungal microbiota was dominated by the yeast species Candida tropicalis across all treatments after $70 \mathrm{~d}$ ensiling (Fig. 3). The relative abundance of Papiliotrema flavescens was reduced in silage containing $40 \%$ pumpkin, compared with the control. In addition, the $20 \%$ carrot silage mixture had a higher relative abundance of Kodamaea ohmeri in comparison with the $100 \%$ maize silage $(\mathrm{P}<0.05)$. No other differences were observed among the 10 most relatively abundant fungal species.

The fungal community structure was not affected by either vegetable mixture $(\mathrm{P} \geq 0.05)$ or the use of an inoculant (Fig. 1C; $\mathrm{P} \geq 0.05$ ) following the aerobic stability trial. In terms of the fungal microbiota of the maize silage, only Monascus purpureus was among the 10 most relatively abundant genera during silage and aerobic stability sampling (Fig. 4). The relative abundance of this species was highly variable, being more abundant in $40 \%$ pumpkin silage, compared to all other treatments, and on average present at $0-2 \%$ in vegetable treatments, compared to $40 \%$ in $100 \%$ maize silage samples following the aerobic stability trial.

Seven of the 10 most relatively abundant bacterial genera were influenced by vegetable treatment in crop maize combined with vegetables prior to ensiling $(\mathrm{P}<0.05$; Supplementary Fig. 1$)$. However, there was no effect $(\mathrm{P} \geq 0.05)$ of vegetable treatment on the relative abundance of Acinetobacter, Gluconobacter and Lactobacillus genera. The control maize treatment was mostly comprised of Klebsiella, Streptococcus and Pediococcus genera, similar to the $20 \%$ DM carrot treatment. Incorporation of carrot at $40 \%$ DM resulted in the largest relative abundance $(\mathrm{P}<0.05)$ of Weissella genera, Pseudomonas genera the most relatively abundant in the $40 \% \mathrm{DM}$ pumpkin treatment $(\mathrm{P}<0.05)$.

In vitro fermentation characteristics. No effects were observed $(\mathrm{P} \geq 0.11)$ on $\mathrm{pH}$ or total VFA concentration of silage containing unsalable vegetables due to vegetable type, level or vegetable type $\times$ level. An increase $(\mathrm{P}=0.01)$ in in vitro dry matter digestibility (IVDMD) was observed with increasing amounts of vegetable in the silage $\mathrm{DM}$. A level $\times$ inoculant interaction was observed for maize silages when considering total gas production and $\mathrm{CH}_{4}$ (Table 4). As the level of pumpkin increased $(\mathrm{P} \leq 0.01)$ in inoculated maize silage $\mathrm{DM}, \mathrm{CH}_{4}$ concentration (expressed as $\mathrm{mg} / \mathrm{g} \mathrm{DM}$ or $\mathrm{mg} / \mathrm{g}$ digestible $\mathrm{DM})$ increased. Conversely, gas $(\mathrm{mL} / \mathrm{g} \mathrm{DM})$ decreased $(\mathrm{P}=0.02)$ as the level of pumpkin increased in maize vegetable silage treated with an inoculant.

Acetic acid and propionic acid percentages of total VFA $(\mathrm{mmol} / 100 \mathrm{mmol})$ increased $(\mathrm{P} \leq 0.03)$ in inoculated maize silage as vegetable inclusion increased (Table 4). Consequently, the ratio of acetic: propionic acids (A:P) in the inoculated vegetable maize silage shifted as acetic and propionic acids increased $(\mathrm{P} \leq 0.01)$. The interaction 


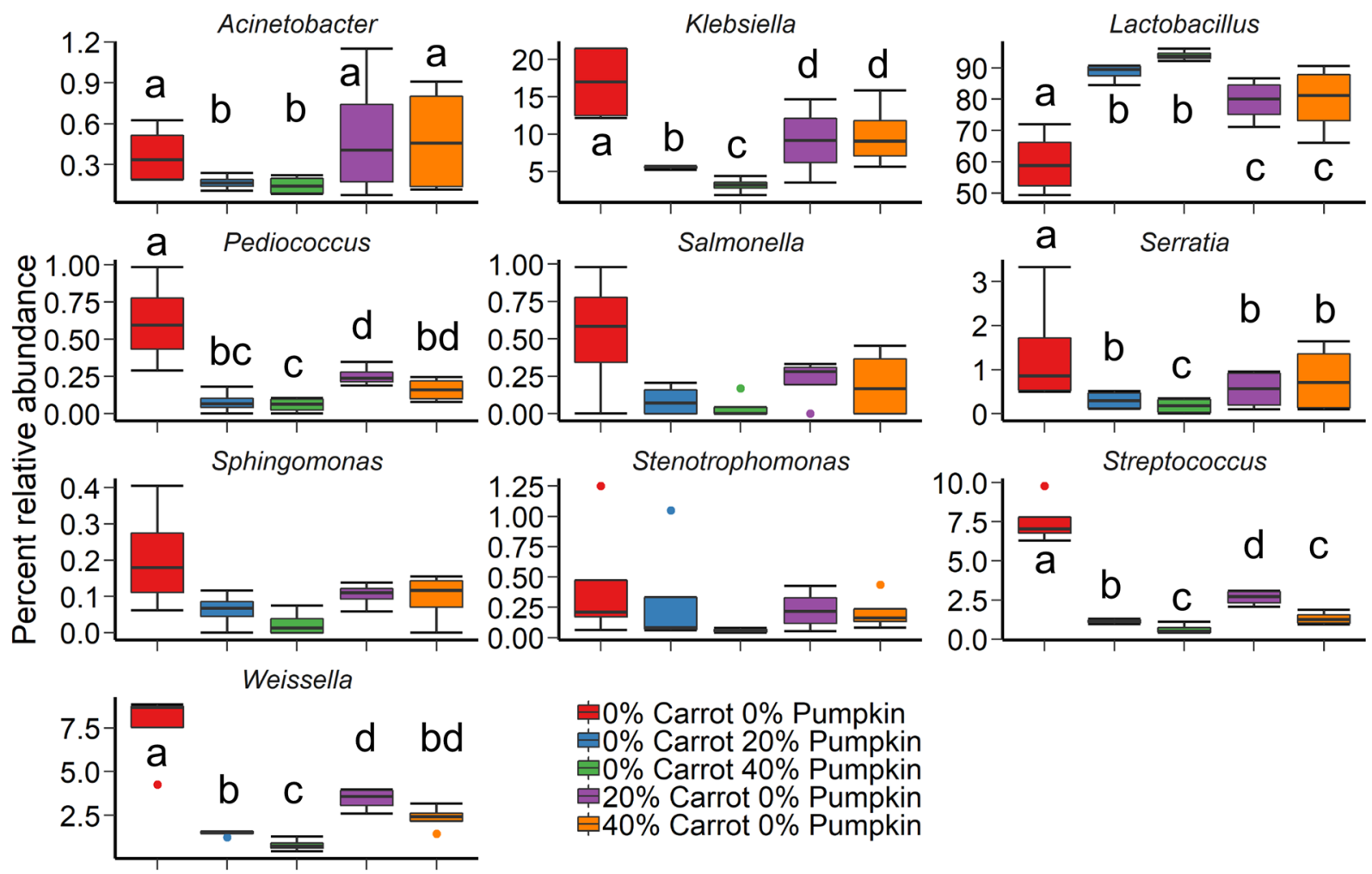

Figure 2. The 10 most relatively abundant bacterial genera in maize ensiled with carrots or pumpkin at 0,20 or $40 \% \mathrm{DM}$, by vegetable mixture, after $70 \mathrm{~d}$ of ensiling. Different lowercase letters indicate significantly different means $(\mathrm{P}<0.05)$.
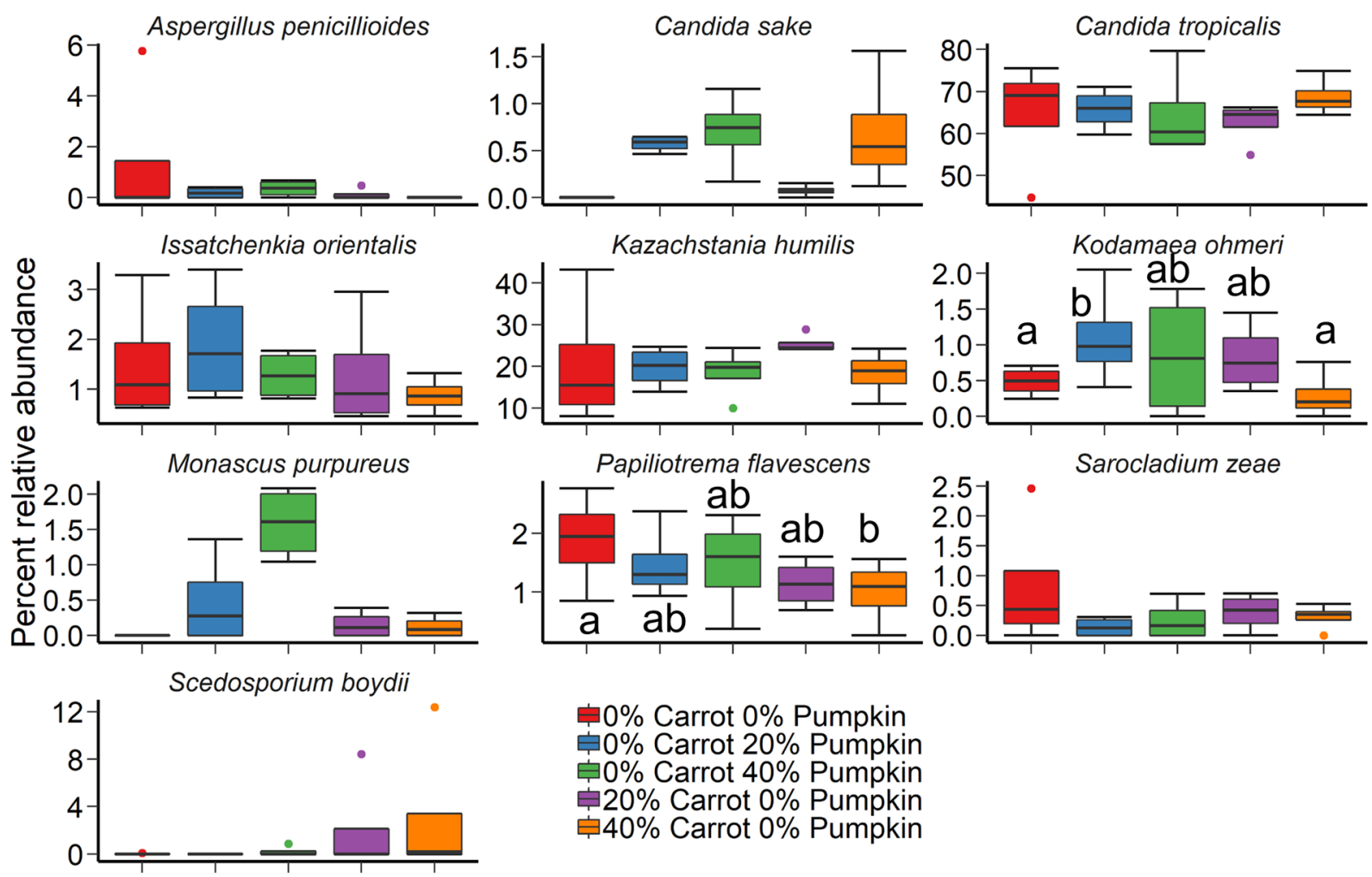

Sarocladium zeae

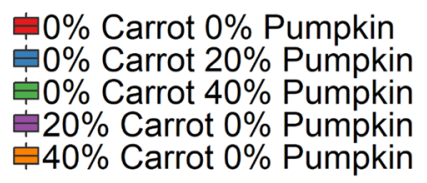

Figure 3. The 10 most relatively abundant fungal species in maize ensiled with carrots or pumpkin at 0,20 or $40 \% \mathrm{DM}$, by vegetable mixture, after $70 \mathrm{~d}$ of ensiling. Different lowercase letters indicate significantly different means $(\mathrm{P}<0.05)$. 


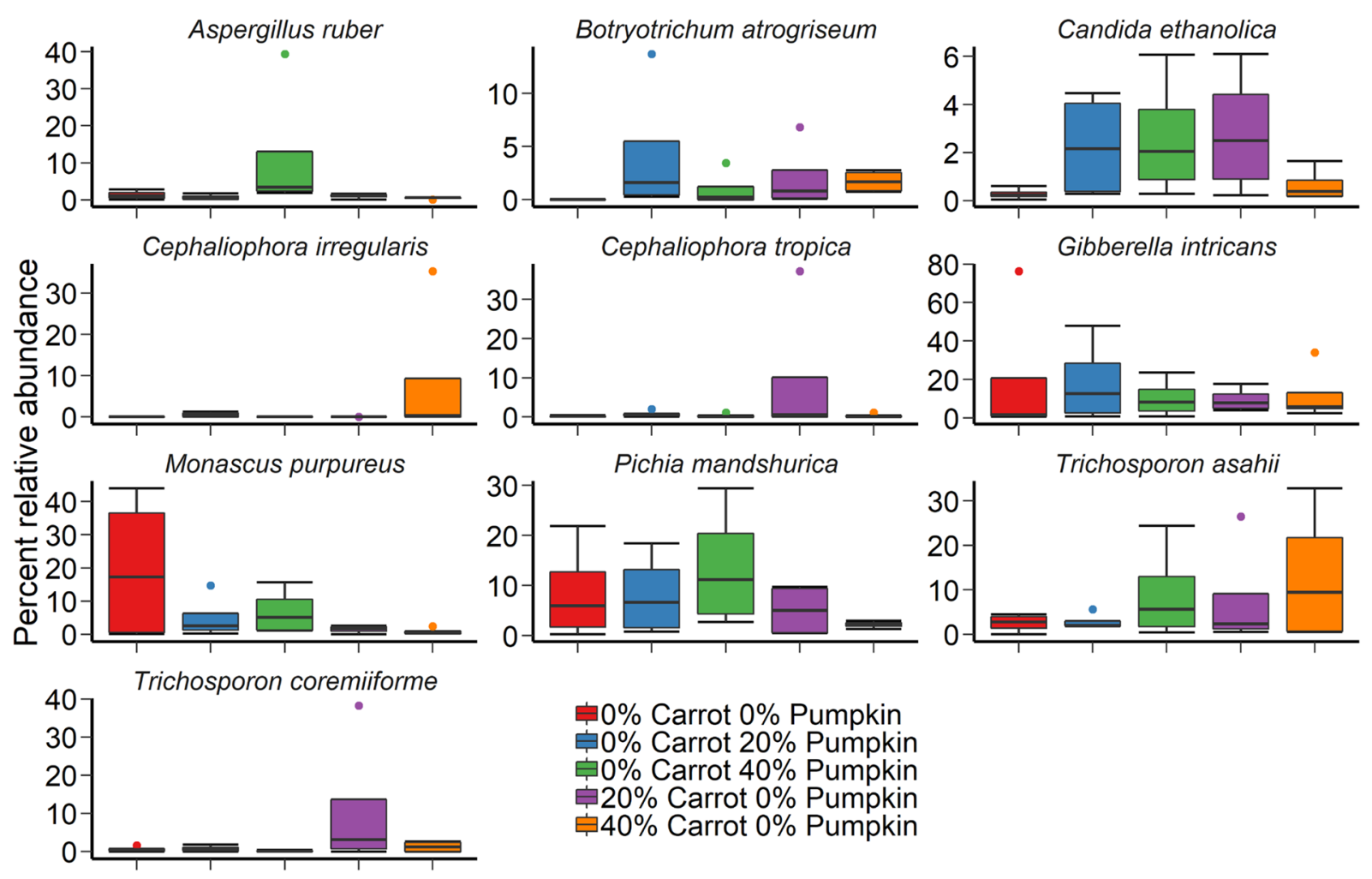

Figure 4. The 10 most relatively abundant fungal species in maize ensiled with either carrots or pumpkin at 0 , 20 or $40 \%$ DM, by vegetable mixture, after day-14 of aerobic exposure.

\begin{tabular}{|c|c|c|c|c|c|c|c|c|c|c|c|c|c|}
\hline & \multirow[b]{2}{*}{0} & \multicolumn{2}{|c|}{ Carrots } & \multicolumn{2}{|c|}{ Pumpkin } & \multirow[b]{2}{*}{ SEM } & \multicolumn{7}{|c|}{ P-values ${ }^{1}$} \\
\hline & & 20 & 40 & 20 & 40 & & Veg & Level & Veg $\times$ Level & Inoculant & Level $\times$ Inoculant & $\mathbf{L}$ & Q \\
\hline Gas mL/g DM & 99.8 & 97.9 & 98.9 & 98.5 & 94.4 & 7.84 & 0.75 & 0.82 & 0.85 & 0.04 & 0.02 & 0.53 & 1.00 \\
\hline $\mathrm{CH} 4, \%$ & 11.9 & 10.7 & 13.7 & 12.5 & 12.8 & 0.7 & 0.61 & 0.11 & 0.24 & 0.11 & 0.10 & 0.09 & 0.17 \\
\hline $\mathrm{CH} 4, \mathrm{mg} / \mathrm{g} \mathrm{DM}$ & 9.0 & 7.7 & 9.9 & 9.1 & 9.3 & 0.87 & 0.61 & 0.2 & 0.29 & 0.02 & 0.002 & 0.43 & 0.12 \\
\hline $\begin{array}{l}\mathrm{CH} 4, \mathrm{mg} / \mathrm{g} \\
\mathrm{DMD}\end{array}$ & 16.4 & 13.1 & 16.8 & 16.8 & 17.1 & 1.47 & 0.2 & 0.27 & 0.28 & 0.01 & 0.001 & 0.65 & 0.13 \\
\hline $\mathrm{pH}$ & 6.2 & 6.2 & 6.1 & 6.2 & 6.2 & 0.04 & 0.77 & 0.08 & 0.71 & 0.07 & 0.65 & 0.67 & 0.0281 \\
\hline IVDMD & 55.8 & 59.6 & 59.5 & 54.5 & 54.4 & 1.7 & 0.01 & 0.68 & 0.19 & 0.12 & 0.29 & 0.47 & 0.62 \\
\hline Total VFA (mM) & 96.3 & 93.1 & 95.3 & 95 & 96.4 & 3.26 & 0.39 & 0.28 & 0.78 & 0.86 & 0.17 & 0.77 & 0.13 \\
\hline \multicolumn{14}{|c|}{ Volatile fatty acids $(\mathrm{mmol} / 100 \mathrm{mmol})$} \\
\hline Acetic (A) & 58.6 & 59.2 & 58.7 & 58.6 & 59 & 0.53 & 0.67 & 0.42 & 0.24 & 0.23 & $<0.0001$ & 0.3 & 0.42 \\
\hline Propionic (P) & 27.2 & 27.2 & 27.5 & 27.5 & 26.9 & 0.41 & 0.71 & 0.9 & 0.44 & 0.42 & 0.03 & 0.92 & 0.66 \\
\hline Butyric & 11.9 & 11 & 11.2 & 11.3 & 11.2 & 0.26 & 0.56 & $<0.01$ & 0.72 & 0.91 & 0.47 & 0.001 & 0.05 \\
\hline Valeric & 0.94 & 0.99 & 1.02 & 1.07 & 1.15 & 0.27 & 0.02 & 0.01 & 0.12 & 0.39 & 0.50 & 0.002 & 0.44 \\
\hline BCVFA & $1.45 \mathrm{~b}$ & $1.51 \mathrm{ab}$ & $1.57 \mathrm{a}$ & $1.61 \mathrm{c}$ & $1.73 \mathrm{a}$ & 0.27 & $<0.01$ & $<0.01$ & 0.02 & 0.04 & 0.36 & $<0.0001$ & 0.79 \\
\hline A:P & 2.2 & 2.2 & 2.1 & 2.1 & 2.2 & 0.04 & 0.88 & 0.99 & 0.32 & 0.36 & 0.003 & 0.99 & 0.88 \\
\hline
\end{tabular}

Table 4. In vitro fermentation characteristics of maize silage ensiled with unsalable carrots or pumpkin after $24 \mathrm{~h}$ of incubation. ${ }^{1} \mathrm{P}$-values for Vegetable $\times$ inoculant $>0.21$; Means with different letters $-\mathrm{a}, \mathrm{b}, \mathrm{c}$ differ $(\mathrm{P} \leq 0.05)$. BCVFA, branched-chain volatile fatty acids (iso-butyric + iso-valeric).

between vegetable $\times$ level led to an increase $(\mathrm{P}=0.02)$ in BCVFA percentage of total VFA, this increase also influenced by inoculant $(\mathrm{P}=0.04)$ added to the silage $\mathrm{DM}$.

\section{Discussion}

The DM content of silage varies greatly, with forage type playing a major role in the rate and degree of fermentation $^{14}$. As expected, the inclusion of unsalable vegetables to maize silage lowered DM content, and increased DM loss during the ensiling process, regardless of the vegetable type (Table 1). Loss of DM in silage occurs through microbial consumption of the forage during the fermentation phase, compounded here using vegetables at 20 or 
$40 \% \mathrm{DM}$ due to the high moisture content, in agreement with previous studies ${ }^{5,7,15}$. However, despite an average $\mathrm{DM}$ of $29-35.3 \%$ at $20 \%$ inclusion and $22.4-31 \% \mathrm{DM}$ at $40 \%$ vegetable inclusion, silage quality, as measured by the $\mathrm{pH}$ at opening $(\mathrm{pH} \leq 4.0)$, was not affected. This aligns with Jalc et al. ${ }^{16}$ who demonstrated that high-moisture maize silages ( $25 \% \mathrm{DM})$ also yield a low $\mathrm{pH}$ of 3.55 .

Vegetable addition to maize silage had no effect on silage surface temperature indicating longevity and quality of the silage was maintained. The use of a second-generation microbial inoculant improved the aerobic stability of silage after 14 days despite no effect of the inoculant on silage $\mathrm{pH}$ at opening. This indicates the high moisture content did not affect the fermentative capacity of the microbial community, in agreement with previous studies reporting microbial inoculants cause a rapid $\mathrm{pH}$ decline in the first 7 days of ensiling, followed by stabilization $^{5,17-19}$. The inoculant used in this study contained a combination of L. plantarum and L. buchneri, well-known for rapidly decreasing silage $\mathrm{pH}$ to prevent microbial spoilage ${ }^{20}$. These findings indicate the benefits of applying the current inoculant to produce greater acetic acid concentrations, thus improving aerobic stability through the inhibition of yeast and mold growth upon aerobic exposure ${ }^{21,22}$.

Crude fat increased up to $3.9 \%$ DM in silage with 20 or $40 \%$ DM vegetable (40\% DM with pumpkin), surpassing the mean crude fat content of $2.84 \%$ for maize silages from a meta-analysis of 234 Brazilian studies $^{23}$. Higher dietary crude fat up to $6-8 \%$ provided to ruminants can increase overall energy intake, beyond that of VFA utilization or protein digestion ${ }^{24}$. However, no difference was observed for NDF contents (\% DM) irrespective of vegetable or proportion of inclusion in the silage DM (Table 1). Despite the high moisture content of carrot and pumpkin, NDF content ranged from $9 \%$ (carrot) to $26 \%$ (pumpkin) for fresh vegetables on a DM-basis ${ }^{7}$. Maize ensiled with green beans have recorded a mean NDF content of $38-45 \%$ at $40 \% \mathrm{DM}^{25}$, similar to values obtained within this study, ranging from 43.3-44.1\% DM NDF for pumpkin and carrots respectively. Contrary to results from this study, NDF quantity has previously been associated with decreased VFA production, although related to organic matter digestibility rather than overall silage quality ${ }^{26}$.

The concentration of total VFA in a silage is not often used as an indicator of silage quality. However, silage that undergoes extensive fermentation is expected to yield a higher total VFA concentration ${ }^{22}$. In the present study, the addition of pumpkin yielded a $4 \mathrm{mM}$ higher total VFA concentration than carrots, through a higher acetic acid concentration with pumpkin silage. Organic matter digestibility may influence VFA concentrations when comparing fresh vegetables or residue silages with a control crop silage ${ }^{27}$. The high organic matter digestibility of pumpkin pulp silages $(60.65 \%)$ surpassed that of a maize silage $(55.35 \%)^{28}$, which could explain the higher proportion of acetic acid, as part of total VFA concentration observed in vegetables silages in this study. Cao et $a l .{ }^{5}$ and Yang et al. ${ }^{17}$ found waste vegetable residues including lettuce, Chinese, red and white cabbage contain epiphytic LAB similar to common livestock forages. Upon ensiling, vegetables with moderately high water-soluble carbohydrate (WSC) contents yielded high VFA concentrations, reduced silage $\mathrm{pH}$ and inhibited harmful aerobic bacteria, yeasts and molds $s^{5,17}$. Furthermore, Yang et al. ${ }^{29}$ noted the positive influence of the addition of a WSC in the form of glucose to wheat straw silage on acid production and the consequential lowering and stabilization of silage $\mathrm{pH}$ during fermentation.

Acetic acid concentrations of silages in this study represented over $90 \%$ of total VFA, but were not affected by silage inoculation. This was unexpected, as silages containing a $2^{\text {nd }}$ generation inoculant are known to yield a high concentration of acetic acid ${ }^{18}$. Typically, a distinct effect of L. buchneri is observed via increased conversion of lactic acid to acetic acid ${ }^{18}$ during the ensiling process. However, this effect may have been diluted by the action of pumpkin in the vegetable silage. Pumpkin, high in both sugars and pectin, provides nutrients that are rapidly consumed by bacteria upon fermentation ${ }^{30}$. A decrease in lactic acid, followed by an increase in acetic acid with 20 or $40 \%$ pumpkin on a DM-basis could explain the minimal effect of the inoculant in this study.

Incorporation of unsalable carrot or pumpkin at 20 or $40 \%$ DM into maize silage was directly correlated with increased bacterial diversity after 70 days of ensiling (Fig. 1). Diverse epiphytic microbial populations have been well documented on root vegetables in contact with the soil rhizosphere ${ }^{31}$. Previous reports have suggested that the epiphytic microbial populations present on carrots are highly diverse, when compared to other vegetables including tomatoes, onions and cucumber ${ }^{32}$. In this study, carrot inclusion influenced the epiphytic bacterial population of the vegetable silages being dominated by Klebsiella, Weissella, Pseudomonas, Salmonella and Streptococcus genera. Carrots can possess an endophytic bacterial population capable of promoting growth of the vegetable ${ }^{33}$ and increasing nitrogen assimilation into plant tissue $\mathrm{e}^{34}$. However Surette et al ${ }^{35}$ identified several genera on carrots, including Agrobacterium and Variovirax, bacteria typically isolated from soil ${ }^{36,37}$ that were not present in the current samples. This difference could be explained as a result of commercial washing of the vegetables with Sodium hypochlorite, which has been previously demonstrated to reduce bacterial counts of Salmonella and Listeria by $2 \log$ at $200 \mathrm{mg} / \mathrm{L}^{38}$. However, the long-term efficacy of sodium hypochlorite to reduce surface pathogens on stored fresh produce is debated. Fresh carrots stored after washing with sodium hypochlorite had an increased coliform load of $3.1 \log$ CFU/g following 6 days storage ${ }^{39}$. In agreement, the carrots ensiled in this study were stored for 3 days prior to ensiling resulting in the presence of Klebsiella being most prominent in silage with carrot inclusion at 20 and $40 \%$ compared to the control, suggesting increasing the vegetable content can increase microbial diversity. Similarly Peng, et al..$^{40}$, observed an increase in bacterial richness with increasing vegetable content, as well as an increase in the number of fungal OTUs in the vegetable silage after 14 days aerobic exposure.

When comparing the inclusion of carrots versus pumpkin in maize silage after 14 days aerobic exposure, the greater bacterial richness observed with the inclusion of carrots could be explained by either the promotion of bacterial diversity by carrots, or the inhibition of bacterial proliferation with pumpkin inclusion. Previously ${ }^{41}$, pumpkin oil extract had no inhibitory effect on any microbes at a maximum concentration of $2.0 \% \mathrm{v} / \mathrm{v}$, despite its rind exhibiting antifungal properties through the proteins $\operatorname{Pr}-1$ and $\operatorname{Pr}-2^{42,43}$. Similarly, Park et al. ${ }^{42}$ determined that $\operatorname{Pr}-2$ acted against pathogenic fungi via damage of the Fusarium oxysporum cell membrane, thereby inhibiting growth of the fungus. However, fungal diversity was not affected by vegetable type in the current study, 
suggesting that pumpkin inclusion did not elicit an antifungal effect. Overall, this suggest the likely disparity in diversity with carrot versus pumpkin inclusion in silage, was due to increased bacterial proliferation with carrot inclusion.

Two fungal species were prominent in the vegetable silage population at $70 \mathrm{~d}$ ensiling - Candida tropicalis and Kazachstania humilis. The fungus $C$. tropicalis is a heat-tolerant yeast that can produce ethanol under mildly acidic conditions $s^{44}$. During the ensiling process, heat production can elevate mean silage temperatures up to $12^{\circ} \mathrm{C}$ above ambient temperature ${ }^{45}$. Hence, the presence of $C$. tropicalis in this study is not surprising, as it has previously been detected in whole maize silage alongside C. quercitrusa ${ }^{46,47}$. However, C. quercitrusa was not detected on the surface of maize silage after 70 days of ensiling in this study. Typically, the detection of both C. tropicalis and C. quercitrusa prior to ensiling and their resultant presence or absence can be attributed to their low tolerance of acetic acid ${ }^{46}$, the quantity of which increased at $40 \%$ pumpkin in the silage DM. Formerly Candida humilis ${ }^{48}$, $K$. humilis has been detected in silage at 45 or $90 \mathrm{~d}$ fermentation ${ }^{49}$. Other members of the Kazachstania genera are often detected on maize silage undergoing aerobic spoilage $e^{50}$. However, little is known about the action of $K$. humilis in the ensiling or aerobic exposure process, except that a higher relative abundance of K. humilis in this instance compared to other fungal species could be influenced by the external environment ${ }^{51}$.

When examining the silages in vitro, a decrease in $\mathrm{CH}_{4}$ production was expected as NDF content declined with 20 or $40 \%$ DM vegetables. However, an inhibitory effect on $\mathrm{CH}_{4}$ did not occur, but rather an increase in methane per gram digestible DM with the use of a silage inoculant was observed. The results corroborate those obtained by Rabelo et al..$^{52}$ and Ellis et al..$^{53}$, where an increase to $40 \%$ vegetables in inoculated maize silage increased gas production and thus, increased $\mathrm{CH}_{4}$ production up to $16.8 \mathrm{mg} / \mathrm{g} \mathrm{DM}$ in the carrot treatment. The digestion of hemicellulose relative to cellulose in a feed can impact $\mathrm{CH}_{4}$ production ${ }^{54}$. More specifically, vegetables such as pumpkin have a hemicellulose:cellulose ratio equal to that of grasses, at $0.67: 1$ on a DM basis ${ }^{55,56}$ which could increase $\mathrm{CH}_{4}$ production upon in vitro incubation ${ }^{56}$. Nevertheless, this was the only observed effect on methane, in agreement with Hristov et al. ${ }^{57}$. In vitro fermentation of pumpkin residues has been shown to increase dry matter digestibility and decrease total gas production ${ }^{58}$, which could decrease total $\mathrm{CH}_{4}$ production proportionally. In this study, there were no effects of ensiled pumpkin on these parameters, which may have been influenced by the stage of maturity, and thus starch content of the crop maize ${ }^{59}$.

In vitro digestibility of carrots has been reported at $71.9 \%{ }^{60}$, correlating with increased silage digestibility with carrot included at 20 or $40 \%$ DM in the current study. Pre-inoculated maize and wheat silages were reported to have increased NDF digestibility at $24 \mathrm{~h}$ in vitro incubation by up to $104 \mathrm{~g} / \mathrm{kg}$ and $236 \mathrm{~g} / \mathrm{kg} \mathrm{DM}$, respectively, compared to the control ${ }^{61}$. However, at $24 \mathrm{~h}$ in vitro incubation, treatment of ryegrass-clover silage using L. plantarum, L. buchneri and Lactobacillus lactus increased $\mathrm{CH}_{4}$ ( $\mathrm{mL} / \mathrm{g}$ of organic matter), attributed to increased gas production and digestibility ${ }^{53}$. This was supported by Rabelo et al..$^{62}$, who identified that L. buchneri used as a silage inoculant increased in vitro gas production and rate of degradability in maize silage, through its preservation of highly digestible water-soluble carbohydrates (WSC). Consistent with the results from this study, Rabelo et al. ${ }^{62}$ ascertained that the proportion of acetic acid increased in maize silage treated with L. buchneri, similar to other experiments conducted into the action of L. buchneri on maize silages, where acetic acid and overall digestibility of inoculated silage increased in rams upon an in vivo study ${ }^{63}$. Laflamme ${ }^{64}$ noted that whole carrots in an alfalfa hay silage at a ratio of 3:1 carrot:hay produced silages of high quality - as observed through its $\mathrm{pH}$ of 4 , low butyric acid ammonia-N concentrations, along with 63\% DM digestibility. As expected, our study yielded lower digestibility and higher $\mathrm{pH}$, given the carrot:hay ratio in the Laflamme ${ }^{64}$ study. As our study had a maximum inclusion level of $40 \%$ carrot or pumpkin, NDF concentration was also distinctly lower at $43.5 \%$ than the reported $56.2 \%{ }^{64}$.

Overall, the results from this study suggest that carrot or pumpkin, combined with crop maize at 20 or $40 \%$ DM decreases bacterial richness and increases the inverse Simpson's diversity index after 70 days ensiling. Such a modification following vegetable inclusion may be beneficial to silage quality, given the resulting dominance of the spoilage-inhibiting Lactobacillus spp. from opening to $14 \mathrm{~d}$ after aerobic exposure. Silage quality was improved with vegetable inclusion evidenced by greater in vitro digestibility. Although no mitigatory effects on in vitro $\mathrm{CH}_{4}$ production were observed in this study, concentrations of acetic acid, which represents over $90 \%$ of the total VFA, increased with carrot or pumpkin at 20 or $40 \% \mathrm{DM}$. Therefore, our results suggest unsalable carrots or pumpkin can be successfully ensiled with crop maize up to $40 \%$ DM to produce a high quality silage, with $40 \%$ $\mathrm{DM}$ inclusion of carrot producing the most desirable nutritional parameters and fermentation characteristics in vitro.

\section{Methods}

Silage production. Crop maize was harvested in January 2018 at The University of Queensland (UQ), Gatton, QLD $\left(27^{\circ} 56^{\prime} \mathrm{S}, 152^{\circ} 28^{\prime} \mathrm{E}\right)$. Unsalable vegetables (carrot and pumpkin) were provided by Kalfresh, Kalbar QLD $\left(27^{\circ} 94^{\prime} \mathrm{S}, 152^{\circ} 57^{\prime} \mathrm{E}\right)$ immediately after grading and transported using a refrigerated vehicle to Gatton within $24 \mathrm{hr}$, vegetables were ensiled within 3 days of grading. A second-generation silage inoculant (SI-LAC ${ }^{\circledR}$ EXTRA, Grevillia Ag, QLD, AUS), containing a combination of homolactic bacteria; L. plantarum and E. faecium and the heterolactic bacterium L. buchneri was used as the silage inoculant.

Maize was harvested over one day, resulting in 2 mini silos per treatment. Accordingly, 20 mini silos were constructed from PVC piping with an attached water valve, at dimensions of $90 \mathrm{~mm}$ diameter by $55 \mathrm{~cm}$ height and a volume of approximately $3500 \mathrm{~cm}^{3}$. Each mini silo was packed using a hydraulic press to a density of $240 \mathrm{~kg} /$ $\mathrm{m}^{3}$. Treatments comprised on a dry matter (DM) basis: (1) $100 \%$ crop maize, control; (2) $20 \%$ carrot with $80 \%$ crop maize; (3) $20 \%$ pumpkin with $80 \%$ crop maize; (4) $40 \%$ carrot with $60 \%$ crop maize; or (5) $40 \%$ pumpkin with $60 \%$ crop maize; where each treatment was replicated to facilitate a control, no inoculant, compared to an inoculant treatment. Each silo was weighed immediately after closing. 
Opening of mini silos. Silage sampling. After 70 days of ensiling, each mini silo was weighed and recorded prior to opening. The top 3-4 cm of silage was disposed from each mini silo due to microbial spoilage. The contents of each mini silo were mixed well, and $100 \mathrm{~g}$ samples were immediately frozen in liquid nitrogen and stored at $-20^{\circ} \mathrm{C}$ for subsequent analyses.

Dry matter content and dry matter loss. Approximately $250 \mathrm{~g}$ of silage from each individual mini silo were used for determination of DM content. Trays were dried at $55^{\circ} \mathrm{C}$ for $48 \mathrm{~h}$. DM loss was calculated as the difference between mini silo wet weight at time of ensiling, and mini silo weight at opening.

$p H$. A sub-sample of silage ( $15 \mathrm{~g}$ ) was blended with $135 \mathrm{~g}$ of distilled water to produce a dilution of $1: 10$, for 30 seconds at room temperature and then filtered through double-layered cheesecloth. Approximately $10-15 \mathrm{~mL}$ of filtrate was used to determine $\mathrm{pH}$ (Activon Model 209, Gladesville, NSW, Australia).

Organic acids, VFA and ethanol. Forty millilitres of filtrate were placed on ice for VFA analyses as described by Zahiroddini et al. ${ }^{65}$. Briefly, samples were centrifuged at $10,000 \times g$ for $15 \mathrm{~min}$ at $4{ }^{\circ} \mathrm{C}$. Supernatant $\left(5 \mathrm{~mL}\right.$ ) was combined with $1 \mathrm{~mL} 25 \%$ (wt/vol) metaphosphoric acid in a ratio of $5: 1$, and frozen at $-20^{\circ} \mathrm{C}$, until analysis by gas-liquid chromatography. Ethanol was determined as previously described by Kudo et al. ${ }^{66}$ on an Agilent technologies 7820A gas-liquid chromatograph system, using a DB-FFAP column of dimensions $30 \mathrm{~m} \times 0.32 \mathrm{~mm} \times 1.00 \mu \mathrm{m}$.

Aerobic stability. Approximately $500 \mathrm{~g}$ of silage per mini silo was placed into two aluminium trays and exposed to ambient temperature for 14 days. Thermal images of each tray were taken from $1 \mathrm{~m}$ for 14 consecutive days at 0900 and 1600, using a FLIR E50 Thermal Imaging Camera (FLIR, Wilsonville, OR, United States of America) and FLIR Tools software. The images provided estimates of the mean, minimum and maximum temperatures for each tray per day, whilst visual assessment of microbial spoilage of the silage was also made each day and recorded. After the 14-day period, the silage samples for each treatment were thoroughly mixed and a sample of $70 \mathrm{~g}$ was collected for DNA extraction of aerobically exposed silage. Samples were frozen in liquid nitrogen and stored at $-20^{\circ} \mathrm{C}$ until DNA extraction.

DNA extraction. Preparation of samples for DNA extraction was conducted as previously described by Yu and Morrison ${ }^{67}$. Briefly, $300 \mathrm{mg}$ of silage was homogenised with $1.1 \mathrm{~mL}$ of InhibitEx buffer. Following bead beating, incubation and centrifugation, $600 \mu \mathrm{L}$ of supernatant was added to $25 \mu \mathrm{L}$ Proteinase-K. Samples were loaded into a QIAGEN QIAcube (Qiagen, Hilden, Germany) for DNA extraction, programmed with the QIAamp Fast DNA Mini Stool Kit protocol. The loaded samples were automatically digested, bound and centrifuged with a spin column, washed twice and eluted. Determination of DNA yield was conducted using a NanoDrop 2000c spectrophotometer (Thermo Fisher Scientific, Wilmington, DE, United States of America) as described by Desjardins and Conklin ${ }^{68}$. Purity and integrity values were obtained through methods identified by Henderson, et al. ${ }^{69}$.

Sequencing and analysis of the bacterial 16S rRNA gene and fungal ITS1 region. The V4 region of the archaeal and bacterial $16 \mathrm{~S}$ rRNA gene was amplified as previously described ${ }^{70}$ using the $515 \mathrm{f}$ Modified (5'-GTGYCAGCMGCCGCGGTAA-3') and 806r modified (5'-GGACTACNVGGGTWTCTAAT-3') primer sequences ${ }^{71}$. The primers ITS1F (5'-CTTGGTCATTTAGAGGAAGTAA-3 $\left.3^{\prime}\right)$ and ITS 2 (5'-GCTGCGTTCTTCATCGATGC- $\left.3^{\prime}\right)^{72}$ were used to amplify the ITS1 region of fungi. Both 16S rRNA gene and ITS1 sequences were sequenced using the MiSeq Reagent Kit v2 (500 cycles; Illumina, Inc., San Diego, CA, USA) and an Illumina MiSeq instrument.

DADA 2 v. $1.8^{73}$ was used in R v. 3.5.1 to process the $16 \mathrm{~S}$ rRNA gene and ITS1 sequences. Briefly, forward and reverse $16 \mathrm{~S}$ rRNA gene sequences were trimmed to 220 and $200 \mathrm{bp}$, merged, and then chimeras were removed. Taxonomy was assigned to the remaining sequences, referred to here as OTUs at $100 \%$ similarity, using the RDP naïve Bayesian classifier and the SILVA SSU database release $132^{74}$. For ITS1 sequences, reads were quality-filtered using the default parameters and a minimum length of $50 \mathrm{bp}$ but were not trimmed to the same length. The reads were merged, chimeras removed, and taxonomy assigned to the ITS1 sequences using the RDP naïve Bayesian classifier and the UNITE database v. 8.075. The number of OTUs per sample, Shannon diversity index, and inverse Simpson's diversity index for $16 \mathrm{~S}$ rRNA gene and ITS1 datasets were calculated in R using Phyloseq v. 1.26.0 $0^{76}$. Bray-Curtis dissimilarities were calculated using vegan $2.5-3^{8,77}$ in R. Prior to analysis, the silage 16S, silage ITS1, crop 16S, and the aerobic stability ITS1 OTU tables were randomly subsampled to 4,450, 2,000, 1,000, and 6,000 sequences per sample, respectively, prior to analysis of alpha- and beta- diversity. All 16S rRNA gene and ITS1 sequences were submitted to the sequence read archive under BioProject accession PRJNA525850.

In vitro and rumen fermentation characteristics. The in vitro experiment was carried out at the University of Queensland Gatton campus. The steers used in this study were cared for under the approval and guidance of the University of Queensland Animal Ethics Committee (AE35581), in accordance with the Animal Care and Protection Act (2001). Two rumen-cannulated Droughtmaster steers had access to ad libitum pasture supplemented daily with $3 \mathrm{~kg}$ carrot and pumpkin each (up to a maximum of $30 \% \mathrm{DM}$ ) for one week prior to the in vitro study. Rumen fluid was obtained from both steers $2 \mathrm{~h}$ post-feeding, rumen fluid collection occurring in the dorsal, anterior ventral, medium ventral, posterior dorsal and posterior ventral regions of the rumen. The pooled rumen fluid was strained through 4 layers of cheesecloth into a pre-warmed, insulated $1 \mathrm{~L}$ Thermos and returned to the laboratory promptly. Methodology details for in vitro incubations and chemical analysis were provided in Williams et al. ${ }^{78}$. 
Statistical analyses. Statistical analyses of the nutrient composition, organic acid and aerobic stability data were obtained using a PROC MIXED SAS ${ }^{79}$, with tabulated results provided as least squares mean and standard error of mean (SEM). The data was analysed as a completely randomized design, with the fixed effects being; vegetable type (carrot vs. pumpkin), level (i.e.: the level of vegetables on a DM basis in the sample; 0, 20 and 40\%) and the interaction between vegetable type and level, whilst the random effect was the mini silo. As the maize silage was harvested on the single day, with 2 replicates per treatment resulting in a total of 20 mini silos, the experimental unit for maize treatments was represented by each mini silo.

Normality of the data was determined using a PROC UNIVARIATE SAS. Orthogonal polynomial contrasts were also used to evaluate the linear and quadratic responses to the differing concentrations of carrots or pumpkins $(0,20$, or $40 \%$ on a DM basis) in the various silage treatments (e.g. maize, inoculant or non-inoculant). Differences among means were determined using a least square linear hypothesis test, with the significance level for all data declared at $\mathrm{P} \leq 0.05$.

Appropriateness of research. This work is within the scope of Scientific Reports, as it provides novel evidence toward the efficacy of forage replacement with unsalable vegetables to create a livestock feed, which would otherwise become waste through conventional disposal methods. The study not only has implications on current knowledge of microbial ecology, nutritive characteristics, aerobic stability in silage, but also societal implications, particularly as food security becomes an increasingly pertinent issue worldwide. Provision of the findings from this study will also allow readers to consider alternative methods of feeding livestock, with the view of further encouraging sustainability in animal production.

\section{Data Availability}

All 16S rRNA gene and ITS sequences were submitted to the Sequence Read Archive under BioProject number PRJNA525436.

\section{References}

1. Makkar, H. P. S. Opinion paper: Food loss and waste to animal feed. Animal 11, 1093-1095, https://doi.org/10.1017/ S1751731117000702 (2017)

2. McGuire, S. FAO, IFAD, and WFP. The State of Food Insecurity in the World 2015: Meeting the 2015 International Hunger Targets: Taking Stock of Uneven Progress. Rome: FAO, 2015. Advances in Nutrition 6, 623-624, https://doi.org/10.3945/an.115.009936 (2015).

3. Ghosh, P. R., Fawcett, D., Sharma, S. B. \& Poinern, G. E. J. Progress towards Sustainable Utilisation and Management of Food Wastes in the Global Economy. International Journal of Food Science 2016, 3563478, https://doi.org/10.1155/2016/3563478 (2016).

4. Wadhwa, M., Bakshi, M. \& Makkar, H. Utilization of fruit and vegetable wastes as livestock feed and as substrates for generation of other value-added products (2013)

5. Cao, Y. et al. Effect of lactic acid bacteria inoculant and beet pulp addition on fermentation characteristics and in vitro ruminal digestion of vegetable residue silage. Journal of Dairy Science 94, 3902-3912, https://doi.org/10.3168/jds.2010-3623 (2011).

6. Carlsson-Kanyama, A. \& González, A. D. Potential contributions of food consumption patterns to climate change. The American Journal of Clinical Nutrition 89, 1704S-1709S (2009).

7. Bakshi, M. Waste to worth: vegetable wastes as animal feed. CAB Reviews: Perspectives in Agriculture, Veterinary Science, Nutrition and Natural Resources 11, https://doi.org/10.1079/pavsnnr201611012 (2016).

8. da Silva Dias, J. C. Nutritional and health benefits of carrots and their seed extracts. Food and Nutrition Sciences 5, 2147 (2014).

9. Das, N., Huque, K., Amanullah, S., Dharmapuri, S. \& Makkar, H. Study of chemical composition and nutritional values of vegetable wastes in Bangladesh. Veterinary and Animal Science 5, 31-37 (2018).

10. Keady, T., Lively, F., Kilpatrick, D. \& Moss, B. Effects of replacing grass silage with either maize or whole-crop wheat silages on the performance and meat quality of beef cattle offered two levels of concentrates. Animal 1, 613-623 (2007).

11. Erkmen, O. Antimicrobial effects of hypochlorite on Escherichia coli in water and selected vegetables. Foodborne Pathogens and Disease 7, 953-958 (2010).

12. Allende, A., Gonzalez, R. J., McEvoy, J. \& Luo, Y. Assessment of sodium hypochlorite and acidified sodium chlorite as antimicrobial agents to inhibit growth of Escherichia coli O157: H7 and natural microflora on shredded carrots. International Journal of Vegetable Science 13, 51-63 (2008).

13. Moon, N. J. Effect of inoculation of vegetable processing wastes with Lactobacillus plantarum on silage fermentation. Journal of the Science of Food and Agriculture 32, 675-683 (1981).

14. Muck, R., Filya, I. \& Contreras-Govea, F. Inoculant effects on alfalfa silage: in vitro gas and volatile fatty acid production. Journal of Dairy Science 90, 5115-5125 (2007).

15. Jiang, Y., Heaven, S. \& Banks, C. Strategies for stable anaerobic digestion of vegetable waste. Renewable Energy 44, 206-214 (2012).

16. Jalč, D., Lauková, A. \& Kišidayová, S. Effect of inoculants on fermentation parameters and chemical composition of grass and corn silages. Slovak Journal of Animal Science 43, 141-146 (2010).

17. Yang, J., Cao, Y., Cai, Y. \& Terada, F. Natural populations of lactic acid bacteria isolated from vegetable residues and silage fermentation. Journal of Dairy Science 93, 3136-3145, https://doi.org/10.3168/jds.2009-2898 (2010).

18. Addah, W., Baah, J., Okine, E. \& McAllister, T. A third-generation esterase inoculant alters fermentation pattern and improves aerobic stability of barley silage and the efficiency of body weight gain of growing feedlot cattle1. Journal of Animal Science 90 , 1541-1552 (2012).

19. Okine, A. et al. Ensiling characteristics of daikon (Raphanus sativus) by-product and its potential as an animal feed resource. Animal Feed Science and Technology 136, 248-264, https://doi.org/10.1016/j.anifeedsci.2006.09.005 (2007).

20. Filya, I. The Effect of Lactobacillus buchneri and Lactobacillus plantarum on the Fermentation, Aerobic Stability, and Ruminal Degradability of Low Dry Matter Corn and Sorghum Silages. Journal of Dairy Science 86, 3575-3581, https://doi.org/10.3168/jds. S0022-0302(03)73963-0 (2003).

21. Reich, L. J. \& Kung, L. Effects of combining Lactobacillus buchneri 40788 with various lactic acid bacteria on the fermentation and aerobic stability of corn silage. Animal Feed Science and Technology 159, 105-109, https://doi.org/10.1016/j.anifeedsci.2010.06.002 (2010).

22. Muck, R. E. Silage microbiology and its control through additives. Revista Brasileira de Zootecnia 39, 183-191 (2010).

23. Bernardi Zardin, P. et al. Chemical composition of corn silage produced by scientific studies in Brazil-A meta-analysis. Semina: Ciências Agrárias 38 (2017).

24. Palmquist, D. L. The role of dietary fats in efficiency of ruminants. The Journal of Nutrition 124, 1377s-1382s, https://doi. org/10.1093/jn/124.suppl_8.1377S (1994). 
25. Nurk, L., Graß, R., Pekrun, C. \& Wachendorf, M. Methane Yield and Feed Quality Parameters of Mixed Silages from Maize (Zea mays L.) and Common Bean (Phaseolus vulgaris L.). BioEnergy Research 10, 64-73, https://doi.org/10.1007/s12155-016-9779-2 (2017).

26. Schulze, A. K. S., Storm, A. C., Weisbjerg, M. R. \& Nørgaard, P. Effects of forage neutral detergent fibre and time after feeding on medial and ventral rumen $\mathrm{pH}$ and volatile fatty acids concentration in heifers fed highly digestible grass/clover silages. Animal Production Science 57, 129-132, https://doi.org/10.1071/AN14261 (2017).

27. Babaeinasab, Y., Rouzbehan, Y., Fazaeli, H. \& Rezaei, J. Chemical composition, silage fermentation characteristics, and in vitro ruminal fermentation parameters of potato-wheat straw silage treated with molasses and lactic acid bacteria and corn silage. Journal of Animal Science 93, 4377-4386 (2015).

28. Ülger, I., Kaliber, M., Ayaşan, T. \& Küçük, O. Chemical composition, organic matter digestibility and energy content of apple pomace silage and its combination with corn plant, sugar beet pulp and pumpkin pulp. South African Journal of Animal Science 48, 497-503 (2018)

29. Yang, H. Y. et al. Effects of water-soluble carbohydrate content on silage fermentation of wheat straw. Journal of Bioscience and Bioengineering 101, 232-237, https://doi.org/10.1263/jbb.101.232 (2006).

30. Halik, G. D., Lozicki, A., Koziorzebska, A., Dymnicka, M. \& Arkuszewska, E. Effect of ensiling pumpkin Cucurbita maxima with the addition of inoculant or without it on chemical composition and quality of silages. Annals of Warsaw University of Life SciencesSGGW. Animal Science 53 (2014).

31. Peiffer, J. A. et al. Diversity and heritability of the maize rhizosphere microbiome under field conditions. Proceedings of the National Academy of Sciences of the United States of America 110, 6548-6553, https://doi.org/10.1073/pnas.1302837110 (2013).

32. Nithya, A. \& Babu, S. Prevalence of plant beneficial and human pathogenic bacteria isolated from salad vegetables in India. BMC Microbiology 17, 64, https://doi.org/10.1186/s12866-017-0974-x (2017).

33. Kõiv, V. et al. Endophytic bacterial communities in peels and pulp of five root vegetables. PLoS One 14(1), e0210542, https://doi. org/10.1371/journal.pone.0210542 (2019).

34. Etminani, F. \& Harighi, B. Isolation and Identification of Endophytic Bacteria with Plant Growth Promoting Activity and Biocontrol Potential from Wild Pistachio Trees. The Plant Pathology Journal 34, 208-217, https://doi.org/10.5423/ppj.Oa.07.2017.0158 (2018).

35. Surette, M., Sturz, A., Lada, R. \& Nowak, J. Bacterial endophytes in processing carrots (Daucus carota L. var. sativus): their localization, population density, biodiversity and their effects on plant growth. Plant and Soil 253, 381-390, https://doi. org/10.1023/A:1024835208421 (2003)

36. Finer, K. R., Fox, L. \& Finer, J. J. Isolation and Characterization of Agrobacterium Strains from Soil: A Laboratory Capstone Experience. Journal of Microbiology \& Biology Education 17, 444-450, https://doi.org/10.1128/jmbe.v17i3.1124 (2016).

37. Loh, J., Pierson, E. A., Pierson, L. S. III, Stacey, G. \& Chatterjee, A. Quorum sensing in plant-associated bacteria. Current Opinion in Plant Biology 5, 285-290 (2002).

38. Pezzuto, A. et al. Effectiveness of Washing Procedures in Reducing Salmonella enterica and Listeria monocytogenes on a Raw Leafy Green Vegetable (Eruca vesicaria). Frontiers in Microbiology 7, https://doi.org/10.3389/fmicb.2016.01663 (2016).

39. Sun, S. H., Kim, S. J., Kwak, S. J. \& Yoon, K. S. Efficacy of sodium hypochlorite and acidified sodium chlorite in preventing browning and microbial growth on fresh-cut produce. Preventive Nutrition and Food Science 17, 210-216, https://doi.org/10.3746/ pnf.2012.17.3.210 (2012)

40. Peng, K. et al. Condensed Tannins Affect Bacterial and Fungal Microbiomes and Mycotoxin Production during Ensiling and upon Aerobic Exposure. Applied Environmental Microbiology 84, https://doi.org/10.1128/aem.02274-17 (2018).

41. Hammer, K. A., Carson, C. F. \& Riley, T. V. Antimicrobial activity of essential oils and other plant extracts. Journal of applied microbiology 86, 985-990 (1999).

42. Park, S. C. et al. Antifungal mechanism of a novel antifungal protein from pumpkin rinds against various fungal pathogens. Journal of Agricultural and Food Chemistry 57, 9299-9304, https://doi.org/10.1021/jf902005g (2009).

43. Park, S. C. et al. $\operatorname{Pr}-1$, a novel antifungal protein from pumpkin rinds. Biotechnology Letters 32, 125-130, https://doi.org/10.1007/ s10529-009-0126-y (2010).

44. Rattanachomsri, U., Tanapongpipat, S., Eurwilaichitr, L. \& Champreda, V. Simultaneous non-thermal saccharification of cassava pulp by multi-enzyme activity and ethanol fermentation by Candida tropicalis. Journal of Bioscience and Bioengineering 107, 488-493, https://doi.org/10.1016/j.jbiosc.2008.12.024 (2009).

45. Borreani, G., Tabacco, E., Schmidt, R., Holmes, B. \& Muck, R. Silage review: Factors affecting dry matter and quality losses in silages. Journal of Dairy Science 101, 3952-3979 (2018).

46. Wang, H., Hao, W., Ning, T., Zheng, M. \& Xu, C. Characterization of culturable yeast species associating with whole crop corn and total mixed ration silage. Asian-Australasian Journal of Animal Sciences 31, 198-207, https://doi.org/10.5713/ajas.17.0183 (2018).

47. Li, Y. \& Nishino, N. Effects of inoculation of Lactobacillus rhamnosus and Lactobacillus buchneri on fermentation, aerobic stability and microbial communities in whole crop corn silage. Grassland. Science 57, 184-191 (2011).

48. Jacques, N. et al. Three novel ascomycetous yeast species of the Kazachstania clade, Kazachstania saulgeensis sp. nov., Kazachstaniaserrabonitensis sp. nov. and Kazachstania australis sp. nov. Reassignment of Candida humilis to Kazachstania humilis fa comb. nov. and Candida pseudohumilis to Kazachstania pseudohumilis fa comb. nov. International Journal of Systematic and Evolutionary Microbiology 66, 5192-5200 (2016).

49. Santos, W. et al. Glycerin as an additive for sugarcane silage. Annals of Microbiology 65, 1547-1556, https://doi.org/10.1007/s13213014-0993-x (2015).

50. Lu, H.-Z., Cai, Y., Wu, Z.-W., Jia, J.-H. \& Bai, F.-Y. Kazachstania aerobia sp. nov., an ascomycetous yeast species from aerobically deteriorating corn silage. International Journal of Systematic and Evolutionary Microbiology 54, 2431-2435 (2004).

51. Carvalho, B. et al. Occurrence of mycotoxins and yeasts and moulds identification in corn silages in tropical climate. Journal of Applied Microbiology 120, 1181-1192 (2016).

52. Rabelo, C. H. S. et al. Effects of Lactobacillus buchneri as a silage inoculant or probiotic on in vitro organic matter digestibility, gas production and volatile fatty acids of low dry-matter whole-crop maize silage. Grass \& Forage Science 72, 534-544, https://doi. org/10.1111/gfs.12273 (2017).

53. Ellis, J. L. et al. The effect of lactic acid bacteria included as a probiotic or silage inoculant on in vitro rumen digestibility, total gas and methane production. Animal Feed Science and Technology 211, 61-74, https://doi.org/10.1016/j.anifeedsci.2015.10.016 (2016).

54. Moe, P. \& Tyrrell, H. Methane production in dairy cows. Journal of Dairy Science 62, 1583-1586 (1979).

55. Ratnayake, R. S., Hurst, P. L. \& Melton, L. D. Texture and the cell wall polysaccharides of buttercup squash 'Delica'(Cucurbita maxima). New Zealand Journal of Crop and Horticultural Science 27, 133-143 (1999).

56. Knapp, J. R., Laur, G. L., Vadas, P. A., Weiss, W. P. \& Tricarico, J. M. Invited review: Enteric methane in dairy cattle production: Quantifying the opportunities and impact of reducing emissions. Journal of Dairy Science 97, 3231-3261, https://doi.org/10.3168/ jds.2013-7234 (2014).

57. Hristov, A. N. et al. SPECIAL TOPICS-Mitigation of methane and nitrous oxide emissions from animal operations: I. A review of enteric methane mitigation options1. Journal of Animal Science 91, 5045-5069, https://doi.org/10.2527/jas.2013-6583 (2013).

58. Crosby-Galván, M. M., Espinoza-Velasco, B. \& Ramirez-Mella, M. Effect of Chihua Pumpkin Residue (Cucurbita argyrosperma) in Ruminal Gas Production and Digestibility in vitro. Pakistan Journal of Zoology 50 (2018). 
59. Brask, M., Lund, P., Hellwing, A. L. F., Poulsen, M. \& Weisbjerg, M. R. Enteric methane production, digestibility and rumen fermentation in dairy cows fed different forages with and without rapeseed fat supplementation. Animal Feed Science and Technology 184, 67-79 (2013).

60. Marino, C. T. et al. Characterization of vegetables and fruits potential as ruminant feed by in vitro gas production technique. Livestock Research for Rural Development 22 (2010).

61. Weinberg, Z. G. et al. Effect of Lactic Acid Bacteria Inoculants on In Vitro Digestibility of Wheat and Corn Silages. Journal of Dairy Science 90, 4754-4762, https://doi.org/10.3168/jds.2007-0176 (2007).

62. Rabelo, C. et al. Effects of Lactobacillus buchneri as a silage inoculant or probiotic on in vitro organic matter digestibility, gas production and volatile fatty acids of low dry-matter whole-crop maize silage. Grass and Forage Science 72, 534-544 Nkosi (2017).

63. B. D., Meeske, R., Langa, T. \& Thomas, R. S. Effects of bacterial silage inoculants on whole-crop maize silage fermentation and silage digestibility in rams. South African Journal of Animal Science 41, 350-359 (2011).

64. Laflamme, L. Carrot/grass silage as cattle feed. Canadian Journal of Animal Science 72, 441-443 (1992).

65. Zahiroddini, H., Baah, J., Absalom, W. \& McAllister, T. A. Effect of an inoculant and hydrolytic enzymes on fermentation and nutritive value of whole crop barley silage. Animal Feed Science and Technology 117, 317-330, https://doi.org/10.1016/j. anifeedsci.2004.08.013 (2004).

66. Kudo, H., Cheng, K. J. \& Costerton, J. W. Interactions between Treponema bryantii and cellulolytic bacteria in the in vitro degradation of straw cellulose. Canadian Journal of Microbiology 33, 244-248, https://doi.org/10.1139/m87-041 (1987).

67. Yu, Z. \& Morrison, M. Improved extraction of PCR-quality community DNA from digesta and fecal samples. BioTechniques 36, 808-812, https://doi.org/10.2144/04365st04 (2004).

68. Desjardins, P. \& Conklin, D. NanoDrop Microvolume Quantitation of Nucleic Acids. Journal of Visualized Experiments, https://doi. org/10.3791/2565 (2010).

69. Henderson, G. et al. Effect of DNA Extraction Methods and Sampling Techniques on the Apparent Structure of Cow and Sheep Rumen Microbial Communities. PLoS One 8, e74787, https://doi.org/10.1371/journal.pone.0074787 (2013).

70. Terry, S. A. et al. Humic substances alter ammonia production and the microbial populations within a RUSITEC fed a mixed hay-concentrate diet. Frontiers in Microbiology 9,1410 (2018).

71. Walters, W. et al. Improved bacterial $16 \mathrm{~S}$ rRNA gene (V4 and V4-5) and fungal internal transcribed spacer marker gene primers for microbial community surveys. Msystems 1, e00009-00015 (2016)

72. Buée, M. et al. 454 Pyrosequencing analyses of forest soils reveal an unexpectedly high fungal diversity. New Phytologist 184, 449-456 (2009).

73. Callahan, B. J. et al. DADA2: high-resolution sample inference from Illumina amplicondata. Nature Methods 13, 581 (2016).

74. Quast, C. et al. The SILVA ribosomal RNA gene database project: improved data processing and web-based tools. Nucleic Acids Research 41, D590-D596 (2012).

75. Kõljalg, U. et al. Towards a unified paradigm for sequence-based identification of fungi. Molecular Ecology 22, 5271-5277 (2013).

76. McMurdie, P. J. \& Holmes, S. phyloseq: an R package for reproducible interactive analysis and graphics of microbiome census data. Plos One 8, e61217 (2013).

77. Oksanen, J. et al. Package 'vegan'. Community ecology package, version 2 (2013).

78. Williams, S. R. O. et al. Influence of feeding supplements of almond hulls and ensiled citrus pulp on the milk production, milk composition, and methane emissions of dairy cows. Journal of Dairy Science 101(no. 3), 2072-2083 (2018).

79. SAS OnlineDoc ${ }^{\circledR}$ 9.3.1 v. 9.3.1,SAS Institute Inc., Cary, North Carolina (2012).

\section{Acknowledgements}

The authors would like to thank Katherine Gzyl and Arun Kommadath for assisting with the processing of 16S rRNA gene and ITS1 sequence data. We also would like to thank Kalfresh (Kalbar, QLD) for their supply of the unsalable vegetables utilized in this study.

\section{Author Contributions}

S.J.M. and A.V.C. designed the study; S.J.M., A.V.C., K.H., D.L.F., E.C., Y.H., D.B.H. collected data; E.C., K.H., D.L.F., Y.H., A.V.C. analyzed the data; D.B.H. conducted bioinformatics; A.V.C. and D.B.H. conducted statistical analysis; K.H., D.L.F., D.B.H., A.V.C. and S.J.M. wrote the manuscript. All authors read and critically revised drafts for intellectual contents and provided approval for publication.

\section{Additional Information}

Supplementary information accompanies this paper at https://doi.org/10.1038/s41598-019-49608-w.

Competing Interests: The authors declare no competing interests.

Publisher's note: Springer Nature remains neutral with regard to jurisdictional claims in published maps and institutional affiliations.

Open Access This article is licensed under a Creative Commons Attribution 4.0 International License, which permits use, sharing, adaptation, distribution and reproduction in any medium or format, as long as you give appropriate credit to the original author(s) and the source, provide a link to the Creative Commons license, and indicate if changes were made. The images or other third party material in this article are included in the article's Creative Commons license, unless indicated otherwise in a credit line to the material. If material is not included in the article's Creative Commons license and your intended use is not permitted by statutory regulation or exceeds the permitted use, you will need to obtain permission directly from the copyright holder. To view a copy of this license, visit http://creativecommons.org/licenses/by/4.0/.

(c) The Author(s) 2019 